\title{
AKUNTABILITAS BIROKRASI \\ DALAM PEMBERDAYAAN MASYARAKAT PESISIR \\ DI KECAMATAN NUSANIWE KOTA AMBON
}

\author{
Ratna Rosmauli Pakpahan \\ ratnarosmauli@gmail.com
}

Dosen Administrasi Publik

Fakultas Ilmu Sosial, Universitas Victory Sorong

\begin{abstract}
Abstrak
Akuntabilitas Birokrasi dalam Pemberdayaan Masyarakat Pesisir di Kecamatan Nusaniwe Kota Ambon.Penelitian ini bertujuan mengetahui dan menganalisis akuntabilitas birokrasi dan faktor-faktor yang mempengaruhi akuntabilitas birokrasi dalam pemberdayaan masyarakat pesisir di Kecamatan Nusaniwe Kota Ambon, serta menemukan konsep baru tentang akuntabilitas birokrasi yang terfokus pada program pemberdayaan masyarakat pesisir. Teknik analisis data yang digunakan adalah teknik anlisis deskriptif kualitatif. Hasil penelitian menunjukkan bahwa akuntabilitas birokrasi dalam tanggung jawab birokrasi dalam mewujudkan tujuan, akuntabilitas birokrasi atas sumber daya, akuntabilitas birokrasi atas keputusan dan akuntabilitas birokrasi dalam membangun partisipasi dalam pelaksanaan program pemberdayaan masyarakat pesisir di Kecamatan Nusaniwe Kota Ambon kurang terlaksanakan dengan baik sebagaimana yang diharapkan. Program pemberdayaan masyarakat pesisir yang dijalankan dalam mewujudkan pengembangan ekonomi masyarakat pesisir, yaitu bantuan modal, bantuan peralatan, dan pelatihan kewirausahaan yang bertujuan untuk memberikan penguatan dalam mewujudkan kemandirian bagi masyarakat pesisir yang rata-rata bermata pencaharian sebagai nelayan yang bergerak di sektor perikanan perdesaan belum juga terlaksana dengan baik. Faktor-faktor yang mempengaruhi akuntabilitas birokrasi dalam pemberdayaan masyarakat pesisir, yaitu : komunikasi, sumber daya, sikap pelaksana, dan struktur birokrasi kurang terlaksana dengan baik sehingga mempengaruhi akuntabilitas birokrasi dalam pelaksanaan program pemberdayaan masyarakat pesisir di Kecamatan Nusaniwe Kota Ambon.
\end{abstract}

Kata Kunci: Akuntabilitas Birokrasi, dan Pemberdayaan Masyarakat Pesisir.

\begin{abstract}
Bureaucratic Accountability in Coastal Community Empowerment in District Nusaniwe Ambon City. This study aims to identify and analyze the accountability of the bureaucracy and the factors that influence bureaucratic accountability in the empowerment of coastal communities in the District Nusaniwe Ambon City, as well as finding new concept of bureaucratic accountability that focuses on the empowerment of coastal communities. The data analysis technique used is descriptive qualitative anlisis techniques. The results showed that bureaucratic accountability within the
\end{abstract}


responsibility of the bureaucracy in realizing the goal, bureaucratic accountability of resources, bureaucratic accountability for decisions and bureaucratic accountability in building participation in the implementation of community development programs in the District Nusaniwe coastal city of Ambon less fulfilled well as expected. Empowerment of coastal communities which are run in realizing the economic development of coastal communities, namely capital, equipment assistance and entrepreneurial training aims to provide reinforcement to achieve independence for the communities which average livelihood as fishermen engaged in the fisheries sector in rural yet well Well done. Factors that influence bureaucratic accountability in the empowerment of coastal communities, namely: communication, resources, executive attitudes, and less bureaucratic structure performing well thus affecting bureaucratic accountability in the implementation of community development programs in the District Nusaniwe coastal city of Ambon.

\section{Keywords: Bureaucratic Accountability and Coastal Community Empowerment.}

\section{Pendahuluan}

Dalam sejarah perkembangan organisasi pemerintah sepanjang eksistensi sebagai pelayan publik terfokus pada pemenuhan kebutuhan dan kepentingan masyarakat sebagai wujud optimalisasi birokrasi pemerintah yang mampu mencapai pelayanan yang efektif dan efisien sesuai dengan prosedur pelayanan yang berlaku. Upaya pencapaiannya pemerintah terus melakukan perubahan melalui langkah debirokratisasi pelayanan dalam pembangunan masyarakat yang mengarah pada paradigma baru pembangunan yang mencari titik keseimbangan antara kepentingan ekonomi dan sosial menuju pembangunan yang humanistik, partisipatif dan memperhatikan sepenuhnya pemberdayaan masyarakat dalam pembangunan perdesaan.

Pentingnya perhatian pemerintah terhadap pengaturan berbagai aset daerah sebagai sumberdaya pembangunan, birokrasi harus mampu mengkoordinir dan menata pembangunan perdesaan menjadi sorotan utama pemerintah dengan memperhatikan berbagai potensi yang ada di desa sebagai wujud bentukan dan pengembangan konsep asli bangsa. Pembangunan perdesaan merupakan pendekatan yang multiestafet dan komprehensif terhadap perubahan masyarakat yang menyangkut aspek sosial, norma, sumber daya (sumber daya alam, manusia, man-made capital) dan juga aspek pasar dan pengambilan keputusan di tingkat lokal. Orientasi birokrasi yang menuju pada pembangunan berbasis perdesaan merupakan alternatif untuk mewujudkan pembangunan yang berbasis penguatan kemampuan masyarakat dalam meniti pembangunan yang menginginkan koordinasi yang baik dalam rangkaian tatanan birokrasi pemerintah dari tingkat provinsi, kabupaten/kota, kecematan, dan 
kelurahan/desa. Oleh karenanya perubahan paradigma pembangunan beriringan dengan perubahan orientasi terhadap pembangunan ekonomi dan wilayah perdesaan. Pembangunan ekonomi dan wilayah perdesaan ini dapat terlaksana jika ditunjang dengan akuntabilitas aparatur yang berada dalam sistem birokrasi pemerintah menyikapi akan tuntutan dan kebutuhan masyarakat dalam pengembangan ekonomi yang berbasis potensi perdesaan. Untuk itu, maka program pemerintah yang diturunkan dalam rangka pemberdayaan masyarakat perdesaan adalah Program Pemberdayaan Masyarakat Pesisir sebagai salah satu alternatif terbaik yang dipilih untuk memenuhi tuntutan pengembangan masyarakat dari sisi struktur birokrasi yang memegang kekuasaan dan kewenangan penuh untuk memacu pertumbuhan ekonomi di tingkat perdesaan.

Terkait dengan itu, peranan birokrasi dalam mengutamakan kepentingan masyarakat melalui pelayanan publik yang diwujudkan dalam mendorong dan menunjang program-program pemberdayaan masyarakat dapat ditelusuri sejak digulirkan beberapa program pemberdayaan terutama Pemberdayaan Masyarakat Pesisir, Departemen Kelautan dan Perikanan (DKP) telah menjangkau 293 kabupaten/kota pesisir di Indonesia dan sampai dengan saat ini diperkirakan semakin bertambah jumlah.

Secara umum program masyarakat pesisir bertujuan meningkatkan kesejahteraan masyarakat pesisir melalui pengembangan budaya kewirausahaan, penguatan Lembaga Keuangan Mikro (LKM) serta penggalangan partisipasi masyarakat dan kegiatan usaha pengembangan ekonomi produktif lainnya yang berbasis sumberdaya lokal dan dilaksanakan berkelanjutan. Pelaksanaan program ini dibagi menjadi tiga periode sebagai berikut (Kusnadi, 2009).

Pertama Periode inisiasi adalah periode membangun, memotifasi, dan memfasilitasi masyarakat pesisir agar mampu mengembangkan Lembaga Ekonomi Masyarakat Pesisir-Mikro Mitra Mina (LEPP-M3) yang telah dibentuk sebagai cikal bakal holding company masyarakat pesisir. Aktivitas periode ini untuk mengatasi masalah rendahnya budaya kewirausahaan masyarakat dan bersumber akses permodalan yang dihadapi oleh masyarakat pesisir. Kedua Periode institusional merupakan periode untuk menjadikan LEPP-M3 sebagai lembaga berbadan hukum koperasi sehingga LEPP-M3 dapat memperluas usaha ekonomi secara legal. Ketiga Periode difarsifikasi merupakan periode perluasan unit usaha Koperasi LPP-M3. Melalui perluasan usaha diharapkan dapat mengurangi ekonomi masyarakat pesisir. 
Adapun dari segi pembangunan masyarakaat pesisir (Coastal Community Development Project) saat ini dilaksanakan sesuai dengan peraturan Dirjen KP3K No.03/PER-DJKP3K/2013. Program-program yang dilaksanakan terfokus dalam menumbuhkembangkan ekonomi melalui pemberdayaan masyarakat pesisir yang meliputi 12 Kabupaten/Kota dalam 10 Provinsi, termasuk Kota Ambon sebagai salah satu lokasi terpilih dalam pelaksanaan program yang didukung oleh pemerintah yang dibuktikan keberlakuan dan keberhasilan dalam lingkupan pembangunan perdesaan dan pengembangan ekonomi masyarakat pesisir di setiap kabupaten/kota dengan sasaran utama pada konteks masyarakat pesisir di perdesaan.

Hal ini mendasari bahwa kondisi masyarakat pesisir/masyarakat nelayan merupakan kelompok masyarakat yang relatif tertinggal secara ekonomi, sosial, dan kultural dibandingkan dengan kondisi masyarakat lain. Kondisi masyarakat pesisir/masyarakat nelayan diberbagai kawasan pada umumnya ditandai oleh beberapa ciri seperti kemiskinan, keterbelakangan social budaya, rendahnya sumber daya manusia (SDM), lemahnya fungsi keberdayaan kelompok usaha bersama (KUB), lembaga keuangan mikro (LKM), dan kapasitas berorganisasi masyarakat. Maka program pemberdayaan masayarakat pesisir merupakan salah satu langkah implementasi kebijakan pemerintah sebagai kepedulian dan tindakan perubahan dalam merespon kondisi yang di alami masyarakat pesisir/masyarakat nelayan.

Namun program program pemberdayaan masayarakat pesisir yang diterapkan pemerintah masih perlu diketahui kemanfaatan dan kontribusinya bagi masyarakat pesisir/masyarakat nelayan secara keseluruhan di wilayah perdesaan. Dengan demikian, penelitian ini terfokus pada program program pemberdayaan masayarakat pesisir di perdesaan tetapi kecenderungannya pada akuntabilitas birokrasi dalam pemberdayaan masayarakat pesisir, yakni desa-desa yang ada di kecamatan Nusaniwe Kota Ambon adalah desa-desa yang merupakan lokasi sasaran diterapkannya program program pemberdayaan masayarakat pesisir dalam perkembangannya sampai saat ini belum diketahui secara pasti ketepatan, kemanfaatan, dan keberhasilan program program pemberdayaan masayarakat pesisir secara menyeluruh dari periode awal sampai periode akhir dari proses pelaksanaan.

Disamping itu dari segi birokrasi dalam membangun pelayanan seiring dengan program program pemberdayaan masayarakat pesisir dibutuhkan pelaksanaan yang sesuai dengan apa yang diinginkan, kenyataannya belum optimal. Masih terdapat hambatan-hambatan yang mewarnai proses pelaksanaan program program 
pemberdayaan masayarakat pesisir selama ini yang menuntut akuntabilitas birokrasi dalam proses tersebut. Mendasari akan hal ini, akan dibuktikan dan di tuangkan secara ilmiah dalam Thesis dengan judul : -Akuntabilitas Birokrasi dalam Pemberdayaan Masyarakat Pesisir di Kecamatan Nusaniwe Kota Ambon.

\section{Rumusan Masalah}

Berdasarkan latar belakang masalah tersebut, maka rumusan masalah dapat disimpulkan dalam penelitian ini:

1. Bagaimanakah akuntabilitas birokrasi dalam pemberdayaan masayarakat pesisir di Kecamatan Nusaniwe Kota Ambon.

2. Faktor-faktor apakah yang mempengaruhi akuntabilitas birokrasi dalam pemberdayaan masyarakat pesisir di Kecamatan Nusaniwe Kota Ambon.

\section{Tujuan Penelitian}

Tujuan yang ingin dicapai dari penelitian ini adalah:

1. Mengetahui dan menganalisis akuntabilitas birokrasi dalam pemberdayaan masyarakat pesisir di Kecamatan Nusaniwe Kota Ambon.

2. Mengetahui dan menganalisis faktor-faktor yang mempengaruhi akuntabilitas birokrasi dalam pemberdayaan masyarakat pesisir di Kecamatan Nusaniwe Kota Ambon.

3. Menemukan konsep baru tentang akuntabilitas birokrasi yang terfokus pada program pemberdayaan masyarakat pesisir.

\section{Landasan Teori}

Konsep Akuntabilitas. Akuntabilitas oleh LAN RI dan BPKP (2001 : 22) menjelaskan akuntabilitas berasal dari bahasa Inggris, yaitu accountability yang artinya keadaan untuk diperetanggung jawabkan, keadaan dapat diminta pertanggung jawabkan. Guna mengungkap suatu konsep pemahaman yang luas, LAN RI dan BPKP (2001 : 22-23) mengutip beberapa sumber sebagai berikut :

1. Menurut The Oxford Advance Learner's Dictionary, akuntabilitas adalah required or expected to give an explanation for one's action. Dengan kata lain, dalam akuntabilitas terkandung kewajiban untuk menyajikan dan 
melaporkan segala tindak tanduk dan kegiatannya terutama di bidang administrasi keuangan kepada pihak yang lebih tinggi/atasannya.

2. Menurut J.B. Ghartey, akuntabilitas ditujukan untuk mencari jawaban terhadap pertanyaan yang berhubungan dengan pelayanan apa, siapa, kepada siapa, milik siapa, yang mana, dan bagaimana.

3. Ledvina V. Carino, mengatakan akuntabilitas merupakan suatu evoluasi kegiatan yang dilaksanakan oleh seorang petugas baik masih berada pada jalur otoritasnya atau sudah berada jauh di luar tanggung jawab dan kewenangannya. Dengan demikian, dalam setiap tingkah lakunya seorang pejabat pemerintah mutlak harus selalu memperhatikan lingkungan. Ada 4 (empat) dimensi yang membedakan akuntabilitas dengan yang lain, yaitu siapa yang harus melaksanakan akuntabilitas; kepada siapa dia berakuntabilitas; apa standar yang digunakan untuk penilaian akuntabilitasnya; dan nilai akuntabilitas itu sendiri.

Terkait dengan pengertian di atas, akuntabilitas (accountability) adalah suatu derajat yang menunjukkan besarnya tanggungjawab aparat atas kebijakan maupun proses pelayanan publik yang dilaksanakan oleh birokrasi pemerintah. Konsep akuntabilitas dalam aplikasinya dapat disesuaikan sesuai dengan kebutuhan jasa pelayanan di jajaran organisasi pemerintah dan dapat disesuaikan pula dengan implementasi program-program pelayanan publik di bidang apapun.

Para administrator publik jelas tidak hanya dituntut untuk kian mampu bekerja secara lebih profesional, efisien, ekonomis dan efektif, tetapi juga akuntabel dan mampu mengembangkan pendekatan-pendekatan yang lebih inovatif guna menjawab tantangan-tantangan baru yang timbul pada aras global, yang langsung atau tidak langsung berpengaruh pada lingkungan tugasnya (De Leon, 1996).

Pejabat/petugas yang berwenang dan bertanggung jawab memberikan pelayanan dan atau menyelesaikan keluhan /persoalan/sengketa diwajibkan memakai tanda pengenal dan papan nama di meja/tempat kerja petugas. Pejabat/petugas tersebut harus ditetapkan secara formal berdasarkan surat keputusan/surat penugasan dari pejabat yang berwenang. Pejabat/petugas yang memberikan pelayanan dan menyelesaikan keluhan harus dapat menciptakan citra positif terhadap penerima pelayanan dengan memperhatikan (Rasminto dan Winarsih, 2006) :

1) Aspek psikologi dan komunikasi, serta perilaku melayani; 
2) Kemampuan melaksanakan empati terhadap penerima pelayanan, dan dapat mengubah keluhan pelayanan menjadi seniman;

3) Menyelaraskan cara penyampaian layanan melalui nada, tekanan, dan kecepatan suara, sikap tubuh, mimik, dan pandangan mata;

4) Mengenal siapa dan apa yang menjadi penerima pelayanan;

5) Berada ditempat yang ditentukan pada waktu dan tempat pelayanan.

\section{Konsep Birokrasi.}

Konsep birokrasi menggambarkan biro (bureau) dan siapa birokrat itu. Downs, Max Weber (dalam Widodo, 2007) mengemukakan karakteristik biro, yaitu -hierarchical organization, impersonality operation, extensive use rules, complexity of administrative task, secrecy, and employment of specially trained personnel on career basis . Oleh karena itu, Downs (dalam Widodo, 2007) biro diartikan sebagai bentuk organisasi yang memiliki empat macam karakteristik utama yaitu :

1) Organisasi berskala besar; memiliki jumlah anggota yang besar

2) Mayoritas diantara anggota orgnisasi sebagai pekerja -full time yang menggantungkan pada pekerjaan organisasi untuk mendapatkan penghasilan (income), dianatara mereka memiliki kompetisi yang tinggi dalam memberikan layanan kepada pasar

3) Promosi dalam biro didasarkan atas penilaian kinerja mereka sesuai dengan peran yang dimainkan dalam organisasi. Bukan didasarkan pada faktor agama, ras, kelas sosial, dan hubungan keluarga yang secara periodik memilih pegawai dari orang yang berada di luar biro

4) Hasil utama bukan dievaluasi secara langsung atau tidak langsung dalam pasar tempat terjadinya secara sukarela.

Akhirnya Downs berhasil menyimpulkan konsep birokrasi kedalam 3 (tiga) pengertian berikut :

-Pertama, birokrasi biasanya menunjuk suatu lembaga atau tingkatan lembaga khusus. Dalam pengertian ini, birokrasi dinyatakan sebagai suatu konsep yang sama dengan biro. Kedua, birokrasi juga dapat berarti suatu metode tertentu yang mengalokasikan sumber daya dalam organisasi yang berskala besar. Pengertian ini sama dengan pembuatan keputusan birokratis (bureaucratic decision making). Ketiga, birokrasi diartikan sebagai -bureauness or -quality that distinguishes bureaus from 
other types of organization. Dalam pengertian ini, birokrasi merujuk pada kualitas yang dihasilkan oleh suatu organisasi .

Dalam konteks, pemberian pelayanan publik dan pembangunan seseorang yang bekerja (dalam istilah birokrat atau aparat atau pegawai) dalam suatu birokrasi (organisasi) hendaklah memainkan perannya sebagai agen pembangunan (development agent), dimana profesionalisme dan etika birokrasi harus diwujudkan. Menurut Widodo (2007), untuk itu suatu birokrasi (organisasi) haruslah membangun karakteristik dari birokrat atau aparat atau pegawai sebagai berikut :

1) Para birokrat harus mengetahui apa yang menjadi tujuan birokrasi

2) Para birokrat harus mengetahu apa yang menjadi tugas dan tanggung jawabnya

3) Para birokrat harus mempunyai kemampuan dan kejelian dalam mengenali, mengidentifikasikan masalah, kebutuhan, dan kepentingan yang dihadapi oleh masyarakat tempat birokrasi berada

4) Para birokrat harus mempunyai kemampuan dalam memobilisasi dan mendayagunakan sumber daya lokal untuk memecahkan masalah dan memenuhi apa yang menjadi kebutuhan dan kepentingan masyarakatnya

5) Para birokrat haruslah membuka kesempatan yang seluas-luasnya pada warga masyarakat untuk berkonsultasi

6) Para birokrat harus berani mengambil keputusan sesuai dengan kompetensi mereka

7) Para birokrat harus senantiasa mendorong dan mengajak masyarakat untuk aktif berpartisipasi dan ikut serta dalam merencanakan dan melaksanakan pembangunan secara terpadu.

Menurut Effendi (1999), sebagai perantara antara negara dan masyarakat, administrasi publik memiliki posisi peranan yang amat pivotal sehingga dapat memainkan peranan yang menentukan dalam menghadapi masyarakat majemuk dengan berbagai dimensi permasalahannya. Namun peranan yang intermediary tersebut belum sepenuhnya berkembang dan bahkan belum mendapatkan perhatian yang cukup memadai dalam teori dan praktek di administrasi publik, walaupun kemajemukan etnis merupakan ciri yang selalu ada pada banyak negara. Dalam literatur administrasi publik umumnya berasumsi bahwa publik yang dilayani adalah masyarakat ideal yang merupakan akumulasi dari individu yang dapat dibedakan atas usia, gender, kawasan tempat tinggal, pekerjaan atau kelas ekonomi, tetapi bukan atas dasar etnisitas. Di banyak negara yang sedang berkembang, kelompok etnis telah dimobilisasi untuk mempertahankan kepentingan kolektif keamanan, status, kesempatan ekonomi dan 
kekuatan politik mereka, guna menghadapi kelompok etnis lain, baik dengan cara damai maupun dengan kekerasan ataupun guna untuk menentang kebijakan dan program pemerintah.

Menurut Thoha (1995) birokrasi merupakan pola kerja pengurusan organisasi. Sekarang semua organisasi besar umumnya dapat digolongkan sebagai birokrasi atau dikelola secara birokratis sekalipun dengan kadar berbeda-beda, terlepas itu organisasi pengejar laba (swasta) atau organisasi nirlaba (lembaga sosial atau pemerintah). Namun yang dimaksud dengan birokrasi di sini adalah pola kerja pengurusan organisasi pemerintah. Tujuan utama birokrasi pada dasarnya adalah menghasilkan sesuatu yang memiliki nilai cepat, tepat dan dengan biaya yang terjangkau (ekonomis). Semua unsur pokok birokrasi mengacu pada upaya rasional untuk mengurus organisasi secara efektif dan efisien. Unsur pokok itu sedikitnya mencakup perlakuan yang sama terhadap semua orang (impersonal), pengisian jabatan atas dasar keahlian dan pengalaman, larangan menyalahgunakan jabatan, standar kerja yang jelas, sistem administrasi yang rapi, serta pengadaan dan pelaksanaan aturan bagi kepentingan organisasi dan mengikat bagi semua anggotanya. Karena itu, tugas utama pemerintah adalah melaksanakan pengaturan dan memberikan pelayanan kepada publik.

Albrow (1989) mengemukakan sejumlah pengertian birokrasi ke dalam hal-hal sebagai berikut:

-(1) organisasi rasional (rational organization): (2) ketidakefisienan organisasi (organizational inefficiency); (3) pemerintahan oleh para pejabat (rule by officials); (4) administrasi negara (public administration); (5) administrasi oleh para pejabat (administration by officials); (6) bentuk organisasi dengan ciri-ciri dan kualitas tertentu, seperti hirarki serta peraturan-peraturan; dan (7) salah satu ciri masyarakat modern yang mutlak (an essential quality of modern society) .

Sedangkan Warwick (Tjokroamidjojo, 2001) memberi batasan ciri-ciri utama birokrasi ke dalam empat tipe, yaitu: pertama, adanya suatu struktur hirarkis yang melibatkan pendelegasian wewenang dari atas ke bawah dalam organisasi; kedua, adanya posisi-posisi atau jabatan yang masing-masing memiliki tugas dan tanggungjawab yang tegas; ketiga, adanya aturan-aturan, regulasi-regulasi dan standarstandar formal yang mengatur bekerjanya organisasi dan tingkah laku para anggotanya; dan keempat, adanya personil yang secara teknis memenuhi syarat, yang dipekerjakan atas dasar karir, dengan promosi didasarkan pada kualifikasi dan penampilan. 
Tipe-tipe birokrasi tersebut seringkali ditemui dalam birokrasi modern. Ini artinya sistem yang dibangun oleh birokrasi modern saat ini lebih kearah pendelegasian wewenang dari atas ke bawah, serta adanya aturan-aturan tertentu yang mengatur polapola hubungan antara pejabat dengan bawahan. Dari sini, kemudian ditemukan menguatnya pembagian wewenang kekuasaan, desakralisasi kekuasaan dan sebagainya.

Kecenderungan birokrasi yang tidak lagi terpusat ini mirip dengan yang dinamakan post-bureaucratic organization. Heckscher dan Donellon seperti dikutip Miftah Thoha (2003) mengemukakan birokrasi masa depan yang tidak lagi mengikuti pola-pola birokrasi Weberian. Menurut keduanya, bentuk organisasi masa depan tidak hanya menempatkan diri pada kohirensi internal dan pemusatan kekuasaan, akan tetapi juga memusatkan pada interaksi eksternal dan interaksi sosial yang berhubungan dengannya. Kekuasaan bukan satu-satunya alat yang ampuh untuk melaksanakan mekanisme birokrasi tanpa diimbangi kewenangan melalui persuasi dan dialog. Powering bukan lagi satu-satunya cara mengendalikan mesin birokrasi pemerintah tanpa harus diimbangi dengan cara-cara yang bersifat empowering.

\section{Konsep Pemberdayaan Masyarakat.}

Pemberdayaan dikenal sebagai terjemahan dari empowerment, yang berarti membuat sesuatu menjadi berdaya atau mempunyai daya atau mempunyai kekuatan. Pemberdayaan sebagai terjemahan dari empowerment menurut Payne (1997 : 266) adalah membantu klien memperoleh daya untuk mengambil keputusan dan menentukan tindakan yang akan dilakukan yang terkait dengan diri mereka, termasuk mengurangi efek hambatan pribadi dan sosial dalam melakukan tindakan melalui peningkatan kemampuan dan rasa percaya diri untuk menggunakan daya yang ia miliki, antara lain melalui transfer daya dari lingkungan. Sementara MacArdle (Sidu, 2006 : 14) mengartikan pemberdayaan sebagai proses pengambilan keputusan oleh orang-orang secara konsekuen melaksanakan keputusan itu. Orang-orang yang telah mencapai tujuan kolektif diberdayakan melalui kemandiriannya, bahkan merupakan -keharusan untuk lebih diberdayakan melalui usaha mereka sendiri dan akumulasi pengetahuan, ketrampilan serta sumber lainnya dalam rangka mencapai tujuan tanpa tergantung pada pertolongan dari hubungan eksternal.

Menurut Shardlow (Roesmidi dan Risyanti, 2006) pemberdayaan membahas bagaimana individu, kelompok ataupun komunitas berusaha mengontrol kehidupan mereka sendiri dan mengusahakan untuk membentuk masa depan sesuai dengan 
keinginan mereka. Pemberdayaan juga mengandung dua pengertian yaitu to give ability or enable to, yakni memberi kecakapan atau kemampuan atau memungkinkan untuk dan to give power or authority to, yakni memberi kekuasaan. Pemberdayaan yang diartikan sebagai suatu pelimpahan atau pemberian kemampuan/kekauatan (power) yang akan menghasilkan hierarki kemampuan atau kekuatan dari ketiadaan kemampuan atau kekuatan, seperti yang dijelaskan Simon (Sidu, 2006) pemberdayaan sebagai suatu aktivitas refleksi, suatu proses yang mampu diinisiasikan dan dipertahankan hanya oleh agen atau subyek yang mencari kekuatan atau penentuan diri sendiri (selfdetermination). Sementara proses lainnya hanya dengan memberikan iklim, hubungan, sumber-sumber dan alat-alat prosedural yang melaluinya masyarakat dapat meningkatkan kehidupannya. Pemberdayaan merupakan sistem yang berinteraksi dengan lingkungan sosial dan fisik. Dengan demikian pemberdayaan bukan merupakan upaya pemaksaan kehendak, proses yang dipaksakan, kegiatan untuk kepentingan pemrakarsa dari luar, keterlibatan dalam kegiatan tertentu saja, dan makna-makna lain yang tidak sesuai dengan pendelegasian kekuasaan atau kekuatan sesuai potensi yang dimiliki masyarakat.

Pada hakekatnya pemberdayaan adalah suatu proses dan upaya untuk memperoleh atau memberikan daya, kekuatan atau kemampuan kepada individu dan masyarakat lemah agar dapat mengidentifikasi, menganalisis, menetapkan kebutuhan dan potensi serta masalah yang dihadapi dan sekaligus memilih alternatif pemecahnya dengan mengoptimalkan sumberdaya dan potensi yang dimiliki secara mandiri. Pemberdayaan sebagai proses menunjuk pada serangkaian tindakan yang dilakukan secara sistematis dan mencerminkan pentahapan kegiatan atau upaya mengubah masyarakat yang kurang atau belum berdaya, berkekuatan, dan berkemampuan menuju keberdayaan. Makna "memperoleh" daya, kekuatan atau kemampuan menunjuk pada sumber inisiatif dalam rangka mendapatkan atau meningkatkan daya, kekuatan atau kemampuan sehingga memiliki keberdayaan. Kata "memperoleh" mengindikasikan bahwa yang menjadi sumber inisiatif untuk berdaya berasal dari masyarakat itu sendiri. Oleh karena itu, masyarakat harus menyadari akan perlunya memperoleh daya atau kemampuan. Makna kata "pemberian" menunjukkan bahwa sumber inisiatif bukan dari masyarakat. Inisiatif untuk mengalihkan daya, kemampuan atau kekuatan adalah pihakpihak lain yang memiliki kekuatan dan kemampuan. 


\section{Program Pemberdayaan Masyarakat Pesisir}

Pada awalnya program pemberdayaan masyarakat pesisir diinisiasi untuk memberdayakan masyarakat pesisir sekaligus mengatasi dampak kenaikan harga BBM terhadap perekonomian masyarakat pesisir, yang difokuskan pada penguatan modal melalui perguliran dana ekonomi produktif (DEP). DEP dilakukan oleh lembaga ekonomi pengembangan pesisir mikro mitra mina (LEPPM3) yang sejatinya dibentuk sebagai cikal bakal holding company milik masyarakat pesisir. Oleh karena itu, dalam jangka panjang program pemberdayaan masyarakat pesisir tetap diarahkan pada :

1) Peningkatan kemandirian masyarakat pesisir melalui pengembangan kegiatan ekonomi, peningkatan kualitas sumber daya manusia (SDM), partisipasi masyarakat, penguatan modal, dan penguatan kelembagaan ekonomi masyarakat pesisir.

2) Penguatan kemampuan masyarakat pesisir untuk mengelola dan memanfaatkan sumberdaya pesisir dan laut secara optimal, berkelanjutan sesuai dengan kaidah kelestarian lingkungan.

3) Pengembangan kemitraan masyarakat pesisir dengan pihak swsta dan pemerintah.

Program pemberdayaan masyarakat pesisir terfokus meningkatkan kesejahteraan masyarakat pesisir melalui pengembangan kultur kewirausahaan, penguatan kelembagaan, penggalangan partisipasi masyarakat serta diverivikasi usaka yang berbasis pada sumberdaya local yang berkelanjutan. Sedangkan sasaran program pemberdayaan masyarakat pesisir adalah masyarakat pesisir skala ekonomi mikro yang dibagi ke dalam dua tahapan sasaran, yaitu:

a. LEPPM3/koperasi perikanan/koperasi lainnya sebagai sasaran antara, dan

b. Sasaran akhir yaitu masyarakat pesisir dengan usaha skala mikro yang berorientasi pada pada sector kelautan dan perikanan seperti kegiatan penangkapan, budidaya, perniagaan hasil perikanan, pengolahan ikan, usaha jasa perikanan serta pengelolaan wisata bahari, yang berlokasi di daerah sekitar pesisir dan pulau-pulau kecil.

Menyangkut kegiatan pokok program pemberdayaan masyarakat pesisir memasuki tahap akhir periode institusionalisasi dan periode diverivikasi, maka kegiatan program pemberdayaan masyarakat pesisir mecakup LKM, SPDN (Solar Pcked Dealer untuk nelayan)/SPBN (Stasion Pengisian BBM untuk nelayan) dan Kedai Pesisir. Dalam pelaksanaannya program pemberdayaan masyarakat pesisir dikelola 
oleh organisasi yang melibatkan beberapa pemangku kepentingan dengan susunan tugas dan fungsi sebagai berikut:

1) Pemerintah Pusat. Pemerintah pusat adalah Departemen Kelautan dan Perikanan (DKP) yang bertindak sebagai penanggungjawab dan pembiona program ditingkat nasional. Penangungjawab kegiatan ini adalah Direktur Jenderal Kelautan, Pesisir dan Pulau-pulau Kecil (Dirjen KP3K) yang bertugas mengelola program ditingkat nasional, seperti penyusunan pedoman umum, melaksanakan sosialisasi regional, pelatihan, monitoring, dan evaluasi serta pelaporan.

2) Pemerintah Daerah. Pemerintah daerah (Pemda) adalah Dinas Kelautan dan Perikanan Provinsi dan Kabupaten/Kota yang menangani program pemberdayaan masyarakat pesisir. Dinas Kelautan dan Perikanan Provinsi sebagai representasi DKP di daerah bertugas melakukan koordinasi sosial, monitoring, dan evaluasi serta pelaporan. Dinas Kelautan dan Perikanan Provinsi juga mengusulkan kabupaten/kota calon penerima pemberdayaan masyarakat pesisir tahun berikutnya berdasarkan hasil evaluasi tahun berjalan. Dinas Kelautan dan Perikanan Kabupaten/Kota sebagai penanggungjawab operasional program, bertugas menetapkan Konsultan Pelaksanaan Kegiatan di Kabupaten/Kota, menetapkan koperasi pelaksana, sosialisasi dan publikasi tingkat kabupaten/kota (fasilitasi pembentukan LKM (bagi kabupaten/kota baru penerima program pemberdayaan masyarakat pesisir), rekruitmen Tenaga Pendamping Desa (TPD), pelatihan, monitoring, dan evaluasi serta pelaporan.

3) Konsultan Manajemen. Konsultan manajemen (KM) berfungsi membantu Dinas Kelautan dan Perikanan kabupaten/kota dalam aspek teknis dan manajemen program pemberdayaan masyarakat pesisir.

4) Tenaga Pendamping Desa (TPD). TPD merupakan tenaga professional di bidangnya yang bersedia tinggal di tengah masyarakat sasaran dan bertugas mendampingi masyarakat secara terus menerus (selama program berlangsung) dalam bentuk mempersiapkan masyarakat pesisir untuk mengakses kredit pada LKM, mendampingi mereka menjalankan dan mengembangkan usaha baik dalam proses produksi maupun pemasaran, membuat laporan pengembangan kegiatan setap bulan kepada Dinas Kelautan dan Perikanan Kabupaten/Kota.

5) Koperasi. Koperasi berfungsi sebagai komponen utama pelaksanaan pemberdayaan masyarakat pesisir di daerah. Dalam pelaksanaan kegiatan koperasi harus berkoordinasi dengan Dinas Kelautan dan Perikanan Kabupaten/Kota sebagai 
penanggungjawab operasional di daerah dan juga dengan lembaga perbankan/pembiayaan sebagai mitra usaha.

6) Bank Pelaksana. Bank pelaksana adalah yang ditetapkan oleh Dinas Kelautan dan Perikanan dengan tugas dan fungsi :

a. Menyediakan kredit bagi kjoperasi sebagai konsekuensi dari adanya DEP yang dijaminkan untuk kegiatan penguatan modal.

b. Menyalurkan DEP langsung dengan hibah melalui rekening koperasi yang ada di Bank pelaksana untu kegiatan pelaksana BPR pesisir, SPDN dan atau kedai pesisir, dan

c. Melakukan pendampingan teknis dan administratif kepada koperasi atau LKM/USP.

\section{Teknik Pengumpulan Data}

Penelitian ini didesain dengan menggunakan metode kualitatif yang mampu menghentar peneliti sampai kepada pencapaian tujuan penelitian. Dalam hal ini dengan metode kualitatif yang digunakan peneliti dapat mengorganisir setiap kegiatan pelaksanaan penelitian sebaik mungkin untuk mencapai hasil penelitian yang diharapkan. Yaitu dengan menggunakan dua studi. Pertama studi kepustakaan (library research) dilakukan peneliti dengan mengumpulkan dan mempelajari. Kedua studi lapangan (field research) yang dimulai dengan merumuskan topik, memilih kelompok sosial atau lingkungan alami dalam penelitian, mengakses dan memilih suatu peran sosial, dan mengamati secara terperinci. Studi lapangan dilakukan dengan wawancara secara mendalam (in depth interview) dengan menggunakan pedoman wawancara.

Sorotan utama objek penelitian ini adalah akuntabilitas birokrasi dalam program pemberdayaan ekonomi masyarakat pesisir pada Kecamatan Nusaniwe Kota Ambon. Melalui penelitian dilakukan analisis dan pengkajian bagaimana program tersebut diterapkan dengan sasaran pada kelompok masyarakat pesisir yang berada di perdesaan yang tidak lain sebagaian besar adalah kelompok masyarakat nelayan yang rata-rata mempunyai tingkat ekonomi yang tergolong rendah dan bahkan masih berada dalam kondisi keterbelakangan dan kemiskinan dibandingkan dengan masyarakat perkotaan yang telah memiliki kemajuan yang baik. 


\section{Teknik Analisis Data}

Analisis data dalam penelitian ini menggunakan teknik analisis data secara kualitatif yang terproses dari pengumpulan data kualitatif menggunakan metode pengamatan yang umumnya digunakan dari tradisi fenomenologi sebagaimana dikatakan oleh Patilima (2005) bahwa data kualitatif dapat diperoleh dari hasil pengumpulan data dan informasi dengan menggunakan berbagai metode pengumpulan data. Seperti wawancara bertahap dan mendalam, observasi partisipasi, diskusi terfokus, dan penjelasan tentang metode data yang dilakukan pada bagian tentang pengumpulan data (Bugin, 2007). Dalam analisis data ini melewati tahapan-tahapan tertentu dalam proses analisis, yakni reliabilitas dan validitas data. Dimana reliabilitas dan validitas data digambarkan melalui triangulasi data, pemeriksaan anggota, pengamatan jangka panjang dan berulang, klarifikasi, pertimbangan masalah, alasan keputusan, menjelaskan pengetahuan tentang masukan, dan mejelaskan masukan yang telah digunakan dalam analisis dan interprestasi data. Melalui proses ini analisis data kualitatif dideskripsikan secara konsisten dan objektif dan pada akhirnya diakhiri dengan suatu kesimpulan yang akurat dan menghasilkan suatu rekomendasi.

\section{Narasumber/Informan Penelitian}

Sebagai pemberi informasi dalam penelitian ini, maka yang menjadi informan adalah mereka yang mengetahui dan mempunyai informasi tentang akuntabilitas birokrasi dalam program pemberdayaan ekonomi masyarakat pesisir pada Kecamatan Nusaniwe Kota Ambon. Informan yang dimaksud dalam penelitian, yaitu Aparat Birokras Dinas Kelautan dan Perikanan Kota Ambon, Pimpinan Lembaga Swadaya Masyarakat Kota Ambon, Kepala-Kepala Desa di Kecamatan Nusaniwe Kota Ambon. Para informan ini adalah mereka yang terlibat dan mengetahui berbagai informasi tentang akuntabilitas birokrasi dalam program pemberdayaan ekonomi masyarakat pesisir pada Kecamatan Nusaniwe Kota Ambon. Sehingga informasi yang aktual dapat diperoleh karena mereka mengetahui hal-hal yang terkait dengan permasalahan dan dianggap representatif dan informatif dalam penelitian ini. 
Akuntabilitas Birokrasi Dalam Pemberdayaan Masyarakat Pesisir Di Kecamatan Nusaniwe Kota Ambon.

Akuntabilitas Birokrasi dalam Pemberdayaan Masyarakat Pesisir yang difokuskan, dikaji dan dianalisis antara lain adalah:

\section{Akuntabilitas Birokrasi dalam Mewujudkan Tujuan}

Akuntabilitas adalah suatu derajat yang menunjukkan besarnya tanggungjawab aparat atas kebijakan maupun proses pelayanan publik yang dilaksanakan oleh birokrasi pemerintah. Akuntabilitas birokrasi dalam mewujudkan tujuan berorientasi pada ketelitian, profesionalitas, dan kejelasan pelaksanaan program program pemberdayaan masyarakat pesisisir. Secara khusus persepsi antara aparat birokrasi, pimpinan LSM, dan kepala-kepala desa, tentang akuntabilitas birokrasi dalam mewujudkan tujuan, yaitu tanggung jawab dalam mewujudkan tujuan pelaksanaan program pemberdayaan masyarakat pesisir menampilkan kontradiksi pernyataan persepsi dari aparat birorasi dengan pimpinan LSM dan kepala-kepala desa, yang mana aparat birokrasi lebih memberikan penegasan positif tentang tanggung jawab birokrasi dalam mwujudkan tujuan pelaksanaan program pemberdayaan masyarakat pesisir yang pada umumnya telah dilaksanakan dengan baik. Tetapi pimpinan LSM tidak searah dengan penegasan itu, yang mana dengan tegas menyatakan bahwa tanggung jawab birokrasi dalam ketelitian, professional dan kejelasan kurang terwujudkan dengan baik.

Hal ini searah dengan penegasan persepsi kepala-kepala desa yang membenarkan bahwa tanggung jawab birokrasi dalam mewujudkan tujuan pelaksanaan program pemberdayaan masyarakat pesisir jelas kurang terwujud dengan baik. Dengan demikian memberikan kepastian tentang akuntabilitas birokrasi dalam mewujudkan tujuan pelaksanaan program pemberdayaan masyarakat pesisir menjadi nyata belum terwudkan dan terlaksanakan dengan baik sebagaimana yang diinginkan.

\section{Akuntabilitas Birokrasi atas Sumber Daya}

Akuntabilitas birokrasi atas sumberdaya tertuju pada ketelitian, profesionalitas, dan kejelasan pelaksanaan program pemberdayaan masyarakat pesisir. Secara khusus persepsi antara aparat birokrasi, pimpinan LSM, dan kepala- 
kepala desa dalam menanggapi akuntabilitas birokrasi atas sumber daya menyangkut tanggung jawab menggunakan dan mendayagunakan sumber daya dalam pelaksanaan program pemberdayaan masyarakat pesisir, membuktikan persepsi yang berlawanan dari segi ketelitian, professional, dan kejelasan.

Dalam hal ini aparat birokrasi lebih banyak menegaskan pada tanggung jawab penggunaan dan pendayagunaan sumber daya oleh birokrasi baik pelaksanaannya, tetapi bagi pimpinan LSM tidak demikian lebih pada pernyataan persepsi yang menunjukan bahwa tanggung jawab birokrasi masih kurang mewujudkan penggunaan dan pendayagunaan sumber daya dalam pelaksanaan program pemberdayaan masyarakat pesisir belum baik dari segi ketelitian, professional, maupun kejelasan dalam penggunaan dan pendayagunaan sumber daya yang dimaksud. Begitu pula dengan dukungan persepsi kepala-kepala desa yang menguatkan pernyataan pimpinan LSM, sehingga hal ini menampakkan bahwa tanggung jawab birokrasi dalam penggunaan dan pendayagunaan sumber daya dalam pelaksanaan program pemberdayaan masyarakat pesisir semakin jelas belum terlaksana secara baik sehingga tentunya hal ini membutuhkan suatu perubahan dalam pelaksanaan.

\section{Akuntabilitas Birokrasi atas Keputusan}

Akuntabilitas birokrasi atas keputusan terarah pada ketelitian, profesionalitas, dan kejelasan pelaksanaan program pemberdayaan masyarakat pesisir. Secara khusus persepsi antara aparat birokrasi, pimpinan LSM, dan kepalalepala desa, jelas adanya silang pandangan dalam penegasan, yakni tanggung jawab atas keputusan menjalankan program pemberdayaan masyarakat pesisir. Aparat berokrasi menekankan ketelitian, professional, dan kejelasan dari akuntabilitas birokrasi melalui tanggung jawab birokrasi atas keputusan dalam menjalankan program pemberdayaan masyarakat pesisir.

Sementara pimpinan LSM menyanggahnya tanggung jawab birokrasi atas keputusan menjalankan program pemberdayaan masyarakat pesisir. Tanggung jawab birokrasi kurang mewujudkan ketelitian, tidak professional, dan kurang memiliki kejelasan dalam hal itu. Kepala-kepala desa juga memastikan demikian, sehingga menguatkan kenyataan bahwa tanggung jawab birokrasi atas keputusan menjalankan program pemberdayaan masyarakat pesisir belum sepenuhnya, yakni masih kurang dalam hal ketelitian, professional, dan kejelasan atas keputusan dalam 
menjalankan program pemberdayaan masyarakat pesisir. Dengan demikian masih perlu adanya suatu langkah tempuh yang dapat mewujudkan pelaksanaan yang efektif dan tepat.

\section{Akuntabilitas Birokrasi dalam Membangun Partisipasi}

Akuntabilitas birokrasi dalam membangun partisipasi mengacu pada ketelitian, profesionalitas, dan kejelasan pelaksanaan program pemberdayaan masyarakat pesisir. Namun secara khusus persepsi antara aparat birokrasi, pimpinan LSM, dan kepala-kepala desa, menunjukkan adanya perbedaan dalam pernyataan mereka tentang akuntabilitas birokrasi dalam membangun partisipasi, yakni tanggung jawab membangun partisipasi pelaksanaan program pemberdayaan masyarakat pesisir menandakan bahwa aparat birokrasi cenderung menggambarkan tanggung jawab birokrasi dijalankan dengan baik dalam artian ketelitian, professional, dan memiliki kejelasan dalam membangun partisipasi dalam pelaksanaan program pemberdayaan masyarakat pesisir. Namun persepsi pimpinan pemberdayaan masyarakat pesisir menepiskan hal itu bahwa tanggung jawab birokrasi dalam membangun partisipasi masyarakat dalam pelaksanaan program pemberdayaan masyarakat pesisir kurang teliti, professional, dan jelas serta didukung pula oleh persepsi kepala-kepala desa menambah kepastian bahwa tanggung jawab birokrasi kurang membangun partisipasi dalam pelaksanaan program pemberdayaan masyarakat pesisir.

5. Pemahaman masyarakat Indonesia yang salah dan keliru mengenai ketahanan pangan yang hanya berkutat pada beras, sedangkan ketahanan pangan itu sendiri memiliki cakupan yang luas bahkan tidak hanya terbatas pada beras perlu diarahkan untuk lebih memahami ketahanan pangan secara benar seperti yang tertuang dalam Undang-Undang Nomor 18 Tahun 2012 tersebut mengenai ketahanan pangan. Ketahanan pangan berarti pangan menjadi sorotan utama. Pangan dan permasalahan yang terjadi didalamnya bukan merupakan masalah baru. Di Indonesia kerawanan pangan pernah terjadi pada periode 1960-an. Saat itu terjadi musim paceklik yang menyebabkan menurunnya semua produksi pertanian di Indonesia sehingga pemerintah terpaksa mengimpor beras dari negara lain. 


\section{Pelaksanaan Program Pemberdayaan Masyarakat Pesisir}

Program pemberdayaan masyarakat pesisir yang dijalankan dalam mewujudkan pengembangan ekonomi masyarakat pesisir, yaitu bantuan modal, bantuan peralatan, dan pelatihan kewirausahaan yang bertujuan untuk memberikan penguatan dalam mewujudkan kemandirian bagi masyarakat pesisir yang rata-rata bermata pencaharian sebagai nelayan yang bergerak di sektor perikanan perdesaan:

\section{Bantuan Permodalan}

Program pemberdayaan masyarakat pesisir dalam bentuk pemberian bantuan modal usaha bagi para nelayan telah dijalankan sesuai dengan prosedur dan ketentuannya tetapi keefektifan dan kefeisiensiannya masih diragukan percepatannya dalam menunjang ekonomi para nelayan sebagai masyarakat pesisir.

\section{Bantuan Peralatan}

Pelaksanaan program pemberdayaan masyarakat pesisir dalam hal pemberian bantuan peralatan tidak dilaksanakan dengan penuh tanggung jawab oleh pihak yang berkewenangan untuk menentukan dan memenuhi tuntutan kebutuhan kelompok nelayan akan bantuan peralatan yang diinginkan. Hal ini membutuhkan perhatian yang serius dalam mengatasi dan menangani pemberian peralatan yang sesuai dengan pengajuan permintaan kelompok nelayan, karena pemberian bantuan peralatan yang memperhatikan kualitas dan daya guna peralatan yang baik dan bertahan lama akan memberikan manfaat yang menguntungkan bagi kelompok nelayan dalam pemanfaatannya untuk memajukan usaha penangkapan ikan.

\section{Pelatihan Kewirausahaan}

Kegiatan pelatihan ini memiliki kriteria lebih dari kegiatan pelatihan yang lain tetapi memiliki kemanfaatan yang sama dalam usaha meningkatkan pendapatan ekonomi kelompok nelayan dan keluarga. Sangat tepat sekali jika mereka sungguhsungguh menekuninya dalam kelompok usaha nelayan sebagai usaha di luar bidang perikanan yang mampu menunjang pekerjaan pokok sebagai nelayan dari hasil usaha mebel. Disamping itu tidak menutup kemungkinan mereka dapat mengembangkannya sebagai usaha kelompok nelayan mandiri. Kelompokkelompok usaha nelayan yang dapat dibangun dengan baik dan pelaksanaannya terfokus dan konsisten serta dikelola dengan pengetahuan, kemampuan, maupun 
skill yang di peroleh melalui pelatihan akan dapat menghasilkan usaha nelayan yang mandiri.

\section{Faktor-Faktor Yang Mempengaruhi Akuntabilitas Birokrasi Dalam Pelaksananan Program Pemberdayaan Masyarakat Pesisir}

Faktor-faktor yang mempengaruhi tanggung jawab birokrasi dalam membangun pelayanan yang benar-benar memacu pelaksanaan program pemberdayaan masyarakat pesisir yang efektif, yakni terdapat empat faktor yang menentukan dan mempengaruhi akuntabilitas birokrasi dalam memacu suksesnya pelaksanaan program sebagaimana dikemukakan oleh George C. Edward III (1980) yaitu :

\section{Komunikasi.}

Tampaknya perbedaan pendapat dalam memberikan keterangan tentang komunikasi sebagai syarat pertama menunjukan bahwa komunikasi yang dibangun melalui koordinasi antarpihak terkait tidak bisa dikatakan telah berjalan dengan baik dalam pelaksanaan program pemberdayaan masyarakat pesisir, yang mana pihak-pihak yang seharusnya dilibatkan ternyata tidak terlibat secara keseluruhan sebagai pelaksana program.

Hal ini tentunya menolak dan tidak membenarkan pendapat yang telah memandang bahwa komunikasi dalam membangun koordinasi dengan pihak terkait berjalan secara efektif dan sekaligus menguatkan dugaan yang dipastikan bahwa komunikasi dalam koordinasi dengan pihak terkait dalam pelaksanaan program pemberdayaan masyarakat pesisir kurang berjalan dengan baik dan efektif. Ini menandakan pula bahwa tanggung jawab birokrasi dalam membangun komunikasi tidak berjalan sebagaimana mestinya. Oleh karena itu komunikasi yang tidak dijalankan dalam membangun kordinasi dengan baik antara pihak-pihak terkait menurunkan dan mempengaruhi akuntabilitas birokrasi sendiri serta akan menjadi hambatan atau kendala dalam pelaksanaan program pemberdayaan masyarakat pesisir.

\section{Sumber Daya.}

Berdasarkan penegasan yang bersifat kontradiksi pandangan di atas, penegasan pertama membuktikan bahwa sumber daya sebagai syarat kedua yang menentukan dalam pelaksanaan program pemberdayaan masyarakat pesisir, pengaturannya dari segi penempatan orang-orang yang berkompetensi dan 
pemanfaatan fasilitas yang mendukung pelaksanaan program pemberdayaan masyarakat pesisir telah berjalan dengan baik yakni tepat dan tertanggung jawab. Hal ini sangat bersifat subyektif karena pada kenyataanya tidak demikian sebagaimana halnya penegasan kedua yang menunjukan bahwa pengaturan sumber daya dan pemanfaatan fasilitas kurang tertuju pada pemenuhan kebutuhan masyarakat dalam pelaksanaan program pemberdayaan masyarakat pesisir yang menjadi hambatan.

Ini jelas sangat objektif dan diakui serta terbukti juga melalui bantuan peralatan yang tidak sesuai dengan kebutuhan yang dialami oleh kelompok nelayan dalam program pemberdayaan masyarakat pesisir sebagaimana telah terungkapkan terlebih dahulu, lebih memperkuat pembuktian bahwa sebenarnya pengaturan sumber daya yang menjadi tanggung jawab birokrasi dalam pelaksanaan program pemberdayaan masyarakat pesisir menjadi jelas kepasitiannya belum terwujud dengan baik. Dengan demikian dinyatakan bahwa dengan pengaturan sumber daya yang tidak efektif maka mempengaruhi akuntabilitas birokrasi dalam pelaksanaan program pemberdayaan masyarakat pesisir karena sumber daya manusia adalah salah satu faktor utama penentu keberhasilan pemberrdayaan.

\section{Sikap Pelaksana.}

Sikap pelaksana sebagai syarat ketiga dalam pelaksanaan program pemberdayaan masyarakat pesisir di atas, menggambarkan bahwa dalam sisi yang sama telah terjadi perbedaan pendapat dalam menanggapi sikap pelaksana dalam pelaksanaan program pemberdayaan masyarakat pesisir, yang mana para pelaksana menunjukkan sikap yang sangat mendukung proses pelaksanaan melalui penerapan setiap kegiatan yang mereka wujudkan sesuai dengan mekanisme pengaturan pelaksanaan program pemberdayaan masyarakat pesisir. Disamping itu pendapat yang menampakan sikap pelaksana belum sepenuhnya mewujudkan percepatan pelaksanaan kegiatan-kegiatan yang mampu mencapai keberhasilan dan tujuan pelaksanaan program pemberdayaan masyarakat pesisir, yang mana setiap kendala yang terjadi tidak direspons dan ditindak lanjuti dengan baik sehingga menjadi masalah yang tidak terselesaikan.

Hal ini menjadi kenyataan yang diakui dalam kepastian penilaian sikap pelaksana dalam pelaksanaan program pemberdayaan masyarakat pesisir karena jelas tidak mendukung secara positif oleh karena terbukti adanya sikap diskriminatif dalam pelaksanaan program, seperti mengutamakan perhatian 
pengurusan dan pelayanan yang lebih mendahulukan kepentingan individu atau kelompok yang memiliki hubungan dekat dengan aparat/pegawai birokrasi sebagaimana yang terjadi pula dalam pemberian bantuan peralatan dalam pelaksanaan program pemberdayaan masyarakat pesisir. Kenyataan ini memastikan bahwa sikap pelaksana yang tidak menunjang pelaksanaan program pemberdayaan masyarakat pesisir secara optimal mempengaruhi akuntabilitas birokrasi dalam pelaksanaan program pemberdayaan masyarakat pesisir.

\section{Struktur Birokrasi.}

Dalam pandangan pelaksanaan program pemberdayaan masyarakat pesisir bahwa para pelaksana program dilayani oleh aparat birokrasi dalam tugas pelayanan sesuai dengan struktur, kewenangan, dan tugas masing-masing dalam melayani setiap kepentingan pelaksanaan program pemberdayaan masyarakat pesisir berdasarkan prosedur pelayanan yang ditetapkan, mempermudah dan mempercepat proses pelayanan yang dibutuhkan. Namun kenyataannya belum tercapai sesuai dengan apa yang diharapkan, selalu terhambat karena lambatnya pelayanan birokrasi yang diwujudkan yang tentunya melewati proses secara terstruktur yang harus melewati rangkaian kewenangan dan tugas masing-masing sehingga jelas menimbulkan ketidak efektifnya pelayanan.

Hal ini mengindikasikan tanggungjawab birokrasi tidak diwujudkan dengan baik dalam pelaksanaan program pemberdayaan masyarakat pesisir. Demikian maka dinyatakan bahwa struktur birokrasi yang memberikan kejelasan kewenangan dan tugas aparat birokrasi sangat menentukan dalam percepatan proses pelayanan dan berpengaruh terhadap akuntabilitas birokrasi dalam pelaksanaan program pemberdayaan masyarakat pesisir. Berbagai keterlambatan pelayanan dalam pelaksanaan program pemberdayaan masyarakat pesisir adalah kepastian dari proses pelayanan birokrasi yang belum tertanggung jawab sepenuhnya dalam operasional tugas secara cepat dan tepat dalam pelaksanaan program pemberdayaan masyarakat pesisir di Kecamatan Nusaniwe Kota Ambon.

\section{Kesimpulan}

Berdasarkan analisis data penelitian yang telah dilakukan dan mengacu pada hasil penelitian yang telah dicapai, maka dapat ditarik beberapa kesimpulan sebagai berikut: 
1. Akuntabilitas birokrasi dalam pemberdayaan masyarakat pesisir, yaitu : akuntabilitas birokrasi dalam mewujudkan tujuan, akuntabilitas birokrasi atas sumber daya, akuntabilitas birokrasi atas keputusan dan akuntabilitas birokrasi dalam membangun partisipasi. Hasil penelitian menunjukan bahwa akuntabilitas birokrasi dalam tanggung jawab birokrasi dalam mewujudkan tujuan, akuntabilitas birokrasi atas sumber daya, akuntabilitas birokrasi atas keputusan dan akuntabilitas birokrasi dalam membangun partisipasi dalam pelaksanaan program pemberdayaan masyarakat pesisir di Kecamatan Nusaniwe Kota Ambon kurang terlaksanakan dengan baik sebagaimana yang diharapkan. Disamping itu program pemberdayaan masyarakat pesisir yang dijalankan dalam mewujudkan pengembangan ekonomi masyarakat pesisir, yaitu bantuan modal, bantuan peralatan, dan pelatihan kewirausahaan yang bertujuan untuk memberikan penguatan dalam mewujudkan kemandirian bagi masyarakat pesisir yang rata-rata bermata pencaharian sebagai nelayan yang bergerak di sektor perikanan perdesaan belum juga terlaksana dengan baik.

2. Faktor-faktor yang mempengaruhi akuntabilitas birokrasi dalam pemberdayaan masyarakat pesisir, yaitu : komunikasi, sumber daya, sikap pelaksana, dan struktur birokrasi. Hasil penelitian menunjukan bahwa komunikasi, sumber daya, sikap pelaksana, dan struktur birokrasi kurang terlaksana dengan baik. Oleh karena komunikasi, sumber daya, sikap pelaksana, dan struktur birokrasi yang tidak dijalankan dengan baik antara pihak-pihak terkait menurunkan dan mempengaruhi akuntabilitas birokrasi sendiri dalam pelaksanaan program pemberdayaan masyarakat pesisir di Kecamatan Nusaniwe Kota Ambon.

\section{Saran}

Mengacu pada kesimpulan tersebut di atas, maka dikemukakan beberapa saran sebagai berikut:

1. Pihak- pihak terkait yang berkompeten dalam pelaksanaan program pemberdayaan masyarakat pesisir di Kecamatan Nusaniwe Kota Ambon, terutama Dinas Perikanan dan Kelautan Kota Ambon hendaknya lebih membangun akuntabilitas sebagai wujud pelayanan dari tugas yang diembankan pemerintah dalam membangun kemandirian masyarakat pesisir. Disamping itu LSM dan Pemerintah Desa sebagai elemen penggerak yang berperan mendukung pelaksanaan program pemberdayaan masyarakat pesisir bersama Dinas Perikanan dan Kelautan Kota 
Ambon perlu membangun partisipasi yang mampu mewujudkan pelaksanaan pemberdayaan masyarakat pesisir secara lebih efektif di Kecamatan Nusaniwe Kota Ambon.

2. Perhatian utama meliputi aspek-aspek akuntabilitas birokrasi, program-program pemberdayaan masyarakat pesisir yang dijalankan, dan faktor-faktor yang mempengaruhi akuntabilitas birokhrasi tersebut, tetap dikedepankan dan menjadi perhatian utama dalam membangun dan mewujudkan pelaksanaan program pemberdayaan masyarakat pesisir secara lebih optimal di Kecamatan Nusaniwe Kota Ambon.

\section{DAFTAR PUSTAKA}

Arfan, Ahmad, 2003, Keberdayaan Komunitas Nelayan dalam Membangun Sarana dan Prasarana Lingkungan Pemukiman (Studi Kasus di Kampung Umapong Desa Kenje Kecamatan Campalagian Kabupaten Poliwali Mamasa) Tesis, Pascasarjana Universitas Gajamada, Yogyakarta.

Basri, Hasan 2003 Pemberdayaan Masyarakat Nelayan, Tesis, Pascasarjana Universitas Brawijaya, Malang.

Borman, Deny Yuliarto Edward, 2007, Peran Pemerintah Daerah dalam Pemberdyaan Nelayan Tradidional (Studi pada Masyarakat Nelayan di Kelurahan Bantaya Kecamatan Parigi Moutong Provinsi Sulawesi Tengah) Thesis, Program Studi Ilmu Administrasi Publik Kekhususan Pemberdayaan Masyarakat Pascasarjana Universitas Brawijaya, Malang.

Chayawati, Dewi, 2009, Implementasi kebijakan Rencana Tata Ruang Wilayah Sulawesi Tengah (Studi Tentang Partisipasi Masyarakat Di Kabupaten Parigi Moutong), Disertasi, Pascasarjana Universitas Padjadjaran, Bandung.

Chozin et.al, 2010, Pembangunan Perdesaan dalam Rangka Peningkatan Kesejahteraan Masyarakat ; Pemikiran Guru Besar Perguruan Tinggi Badan Hukum Milik Negara, Bogor : IPB Press.

Creswell, John W., 1994, Research Deasin Quantitative and Qualitative Approach, London : Sage Publication Inc.

Bugin, Burhan, 2007, Metode Penelitian Kualitatif : Komunikasi, Ekonomi, Kebijakan Publik, dan Ilmu-ilmu Sosial lainnya, Jakarta : Kencana.

Edward III, George C., 1980, Implementating Public Policy, Washington : Congressional Quarterly Inc. 
Hadi, Rachman, 2007, Implementasi program Community Development Dalam meningkatkan kemandirian Masyarakat (Studi Pada Perusahaan Migas di Kabupaten Indramayu), Disertasi, Pascasarjana Universitas Padjadjaran, Bandung.

Islami, M., Irfan, 2003, Prinsip-Prinsip Perumusan Kebijakan Negara, Jakarta: Sinar grafika.

Kusnadi, 2009, Keberdayaan Nelayan dan Dinamika Ekonomi Pesisir, Yogyakarta : Kerja Sama Pusat Penelitian Wilayah Pesisir dan Pulau-pulau Kecil Lembaga Penelitian Universitas Jember dengan AR-Ruzz Media.

Lubis, S.B., Hari dan Husaeni, Martani, 1987, Teori Organisasi (Suatu Pendekatan Makro), Jakarta : PAUIS-UI

Marviandi, Eripto,2006 Strategi Bertahan Hidup Dan Adaptasi Nelayan Tradisional Desa Koja Doi Terhadap Program Pemberdayaan Masyarakat, Tesis, Pascasarjana Universitas Brawijaya, Malang.

Ndraha, Taliziduhu, 1990, Pembangunan Masyarakat, Jakarta : Rineka Cipta. ,2000, Teori Budaya Organisasi, Pascasarjana Unpad Bandung : BKU Ilmu Pemerintahan.

Osborne David \& P. Plastrik, 2004, The Price of Goverment, Getting the Results We Need in An Age of Parmenent Fiscal Crisis. Canbridg, MA : Basic Books.

Patilima, Hamid, 2007, Metode Penelitian Kualitatif, Bandung : Alfabeta.

Pattimukay, Hengky, V. R., 2008, Peranan Administrasi Publik Dalam Pembangunan Sosial Pemberdayaan Masyarakat, Jurnal : Hipotesa Vol. 2 No. 2 November ISSN 08528977.

Payne M., 1997, Social Work Community Care, London : MacMillan.

Putra, Fadillah, 2001, Paradigma Kritis dalam Studi Kebijakan Publik, Yogyakarta : Pustaka Pelajar.

Roesmidi H dan Riza Risyanti, 2006, Pemberdayaan Masyarakat, Jatinangor : Alqaprint.

Lukman, Sampara, 1999. Manajemen Kualitas Pelayanan. STIA-LAN Press, Jakarta. Saputra, 2000, Pengembangan SDM dan Perspektif Organisasi, OKP Karya Pemuda, Vol 5.

Siagian, Sondang, P., 2003, Filsafat Administrasi, Jakarta : Bumi Aksara.

Sidu, Dasmin, 2006, Pemberdayaan Masyarakat Sekitar Kawasan Hutan Lindung Jompi Kabupaten Muna Provinsi Sulawesi Tenggara; Disertasi, Pascasarjana Institut Pertanian Bogor.

Sinambela Lijan Poltak, dkk, 2005. Reformasi Pelayanan Publik : Teori Kebikakan, dan Implementasi. Bumi Aksara, Jakarta. 
Stoner, James, A.F., 1992, Management, Prentice Hall Inc. Eng Lewood Clifs. N.J.

Suharto, Edi, 2005, Membangun Masyarakat Memberdayakan Rakyat, Bandung : Alfabeta.

, 1997, Pembangunan, Kebijakan Sosial dan Pekerjaan Sosial Spektrum

Pemikiran, Bandung : Lembaga Studi Pembangunan STKS (LSP-STKS).

Suhendra K., 2006, Peranan Birokrasi dalam Pemberdayaan Masyarakat, Bandung : Alfabeta.

Suyanto, Bagong, 1996, Perangkap Kemiskinan, Problem Dan Strategi Pengentasannya, Surabaya : Airlangga University Press.

Thoha, Miftha, 1998, Pembangunan Administrasi di Indonesia, Deregulasi dan Debirokratisasi Dalam Upaya Meningkatkan Mutu Pelayanan Masyarakat, Jakarta : LP3S.

Wahab, Solihin, 2002, Analisis Kebijaksanaan dari Formulasi ke Implementasi Kebijaksanaan Negara, Jakarta: Bumi Aksara.

Wasistiono, Sadu, 1998, Pemberdayaan Aparatur Daerah, Bandung : Abdi Praja.

Widodo, J, 2006, Pengolahan Sumber Daya Perikanan Laut, Yogyakarta : Gadjah Mada University Press.

, 2001, Good Governance: Telaah dari Dimensi Akuntabilitas dan Kontrol Birokrasi pada Era Desentralisasi dan Otonomi Daerah, Surabaya : Insan Cendikia.

Dokumen:

Direktorat Pemberdayaan Masyarakat Pesisir, 2005, Pedoman Umum Pemberdayaan Ekonomi Masyarakat Pesisir, Jakarta : Dirjen Kelautan.

Badan Pusat Statistik Kota Ambon, Data Kependudukan 2010-2011

Pemerintah Daerah Provinsi Maluku, 2009, Maluku 